\title{
Friction and Wear Resistance for Polyetheretherketone Filled with Different Filler Materials: A Comparative Study
}

\author{
Dalia M.T. Mustafa \\ Dept. of Production Eng. \& Metallurgy \\ College of Engineering \\ Sulaimani Polytechnic University \\ Sulaimani, Kurdistan- Iraq \\ dalia.89@hotmail.co.uk
}

\author{
Sarkawt Rostam \\ Dept. of Production Eng. \& Metallurgy \\ College of Engineering \\ Sulaimani Polytechnic University \\ Sulaimani, Kurdistan- Iraq \\ sarkawt.rostam@spu.edu.iq
}

\begin{abstract}
Friction and wear behavior of Polyetheretherketone (PEEK) filled with different filler composites were compared. The comparisons were made for different scholar research works which were published between 1987 - 2017.

The comparison took place between different filler composites such as carbon fiber $(\mathrm{CF})$ reinforced Polyetheretherketone, nanometer $\mathrm{Al}_{2} \mathrm{O}_{3}$, nanometer SiC, polytetrafluoroethylene (PTFE) filled PEEK, nanometer $\mathrm{ZrO}_{2}$, nanometer $\mathrm{SiO}_{2}$, nanometer $\mathrm{Si}_{3} \mathrm{~N}_{4}$, $\mathrm{CUS}$, short fiber reinforced PEEK composites, PEEKCF30, GO-Si and Graphite composites.

The friction and wear were studied according to different factors of the filler composites such as plasma treated PEEK, volume percentage, weight percentage, sliding distance, surface of roughness, and size of particles.

By this work we can understand the effect of some nanometer particles which act as fillers in polyetheretherketone, and by this comparison study we conclude that friction and wear properties can be decreased or increased or stay unchanged by increasing and decreasing the amount of fillers but it can be improved by adding different fillers with certain properties to obtain optimal results.
\end{abstract}

Keywords: Polyetheretherketone, friction, wear, filler composites.

\section{INTRODUCTION}

As a result of good properties such as low coefficient of friction, good corrosion resistance and temperature resistance, and low density, polymers have many applications which are car parts, medicine, electronic components and medical supplies.

Polyetheretherketone (PEEK) is a newly developed high performance aromatic thermoplastic. It's a semicrystalline polymer with high melting temperature.

The coefficient of friction and the wear rate are two important parameters in characterizing the tribological performance of the composites. The coefficient of friction is defined as the ratio of the tangential friction force and the normal load, while wear rate is defined as the composite loss caused by wear.

Studies were done to show the effect of friction and wear of polymers in dry conditions, but less studies were on the effect of friction and wear of polymers in water.

Some studies were made to show the effect of friction and wear of peek and its composites which were filled with fibers, inorganic fillers and polymers. One of the most effective fillers to reduce wear rate was PTFE [13]. $\mathrm{SiC}$ as filler is very important in reducing friction and wear. Since carbon fiber (CF) has very good mechanical properties for example high modulus and strength, and it's prevalent as fillers in reducing friction and wear [4-13]. Studying the effect of friction and wear was obtained for 316L across PEEK and CFRPEEK, and 9Cr18Mo across CFRPEEK, by testing them on ring-ondisc tester.

Stainless steel 316L and 9Cr18Mo were positioned on the top respectively. The bottom specimen was made of PEEK and CFRPEEK respectively [14].

An experimental work was made to study the act on of the particles of $\mathrm{Al}_{2} \mathrm{O}_{3}$ on friction and wear resistance when peek is filled with it, and also when PEEK is filled with PTFE. The powder of PEEK was mixed up with the nanometers of $\mathrm{Al}_{2} \mathrm{O}_{3}$ and PTFE by using mechanical method, with amount of 5 mass $\% \mathrm{Al}_{2} \mathrm{O}_{3}$ and $10 \%$ PTFE [15].

PEEK fine powders of diameter 100 micrometer and nanometer $\mathrm{ZrO}_{2}$ which was used as filler were used. The machine which was used for testing friction and wear was M-200 [16].

Another work was to investigate the effect of $\mathrm{Si}_{3} \mathrm{~N}_{4}$ particles as filler in peek. The PEEK fine powders used, of a diameter of 100 micrometer, nanometer $\mathrm{Si}_{3} \mathrm{~N}_{4}$ (with size of less than $50 \mathrm{~nm}$ ) was used as the filler. The samples were arranged by squeezing the dried composite [17].

Another study was to show the effect of PEEKCF30 beneath lubrication circumstances $[11,13]$. Friction and wear resistance of PEEK-CF30 which was slides against steel was studied [8].

A comparison was made to show how the effect of addition of PTFE to $\mathrm{CuS}$ on friction and wear resistance was studied; they were used in fine powder form [18]. For $\mathrm{SiC}$ and $\mathrm{SiO}_{2}$, they were also used as powders, it can be seen that $\mathrm{SiC}$ is harder and less brittle than $\mathrm{SiO}_{2}$.The test was done on an M-200 model tester [19].

For GO-Si, GO nano-sheets Graphene oxide nanosheets were prepared. For tribological behavior a universal micro-tribotester was used [20]. 
For short fiber reinforced PEEK composites, different materials were used and a "Pin on Ring" tester was used [21].

Graphite is considered as an important solid lubrication which is used for improving friction coefficient. The PEEK matrix (melt index: $24 \mathrm{~g} / 10$ min) and different particle sizes of micron-graphite were used. A UMT-2 model friction and wear tester was used [22].

The rest parts of this research paper are classified as follows. Section 2 contains the methodology used in this work to review the literature covered from 1987-2017. This is followed by results and discussion in Section 3. Conclusions stated in Section 4.

\section{METHODOLOGY}

A review paper, which contains different studies of many scholarly journals, were collected as a research methodology to make a framework for studying friction and wear rate in Polyetheretherketone filled with different fillers.

The review paper was made to collect the researches in highest ranking journals, 1987 was chosen as a starting date for search. And 2017 was chosen for the last paper research.

A comparison was carried out for studying the effect of adding different filler composites to polyetheretherketone to friction and wear rate, these data were taken from different research papers. For this purpose Tables 1- 6 were made for different data according to:

(1) Composite material: fiber (CF) reinforced Polyetheretherketone (PEEK), nanometer $\mathrm{Al}_{2} \mathrm{O}_{3}$, nanometer $\mathrm{SiC}$, polytetrafluoroethylene (PTFE) filled PEEK, nanometer $\mathrm{ZrO}_{2}$, nanometer $\mathrm{SiO}_{2}$, nanometer $\mathrm{Si}_{3} \mathrm{~N}_{4}$, CuS, short fiber reinforced PEEK composites, PEEK-CF30, and Graphene/PEEK.

(2) Filler composites parameters such as: volume percentage, weight percentage, sliding velocity, normal load, temperature, and size of particles.

\section{RESULTS AND DISCUSSION}

In this section the data collected from the reviewed literature tabulated in six tables to show how when peek is filled with different composites will change the friction and wear resistance.

As shown in Table 1, the friction coefficient of 316LCFRPEEK and 9Cr18Mo-CFRPEEK was much lower than that of 316L-PEEK. We see that friction coefficient became $0.16-0.25$ later when it was run for $40 \mathrm{~min}$. It has shown that the friction coefficient of CFR-PEEK became 0.1 till the experiment came to end. From Table 1 it can be appear that the friction coefficient of 9Cr18Mo-CFRPEEK became $0.1-0.15$ before $60 \mathrm{~min}$ [14].
Table 1 Carbon fiber (CF) reinforced (PEEK) [14]

\begin{tabular}{|c|c|c|}
\hline \multicolumn{3}{|c|}{ Carbon fiber (CF) reinforced (PEEK) } \\
\hline $\begin{array}{c}\text { Filler composite } \\
\text { material }\end{array}$ & Friction & Wear rate \\
\hline 316 L PEEK & $\begin{array}{l}0.16-0.25 \text { (After } \\
40 \mathrm{~min})\end{array}$ & - \\
\hline 316 L CFR PEEK & 0.1 (until end) & - \\
\hline $\begin{array}{l}\text { 9Cr18Mo-CFR } \\
\text { PEEK }\end{array}$ & $\begin{array}{l}0.1-0.15 \text { (Before } \\
60 \mathrm{~min})\end{array}$ & $\begin{array}{l}<316 \mathrm{~L} \\
\text { PEEK } \\
>316 \mathrm{~L} \mathrm{CFR} \\
\text { PEEK }\end{array}$ \\
\hline
\end{tabular}

Table 2 PEEK filled nanometer $\mathrm{Al}_{2} \mathrm{O}_{3}$ and $\mathrm{ZrO}_{2}[15,16]$

\begin{tabular}{|c|c|c|c|}
\hline \multicolumn{4}{|c|}{ PEEK filled Nanometer $\mathrm{Al}_{2} \mathrm{O}_{3}$} \\
\hline Filler & Particle size & Friction & Wear rate \\
\hline \multirow{2}{*}{$\mathrm{Al}_{2} \mathbf{O}_{3}$} & $15 \mathrm{~nm}$ & $\begin{array}{l}\text { Higher } \\
\text { Friction } \\
\text { coefficient }\end{array}$ & $\begin{array}{l}\text { Lowest wear } \\
\text { coefficient }\end{array}$ \\
\hline & $90 \& 500 \mathrm{~nm}$ & lower friction & $\begin{array}{l}\text { Little more } \\
\text { than Twice of } \\
15 \mathrm{~nm}\end{array}$ \\
\hline $\begin{array}{l}\text { Peek- } \\
\text { Al2O3- } \\
\text { PTFE }\end{array}$ & & $\begin{array}{l}\text { lower friction } \\
\text { Coefficient }\end{array}$ & $\begin{array}{l}\text { Increased } \\
\text { wear } \\
\text { coefficient }\end{array}$ \\
\hline \multicolumn{4}{|c|}{ PEEK filled Nanometer $\mathrm{ZrO}_{2}$} \\
\hline \multirow[b]{2}{*}{$\mathrm{ZrO}_{2}$} & $<15 \mathrm{~nm}$ & $\begin{array}{l}\text { Reduce } \\
\text { friction }\end{array}$ & $\begin{array}{l}\text { Sharply } \\
\text { decreased }\end{array}$ \\
\hline & $>50 \mathrm{~nm}$ & $\begin{array}{l}\text { Increase } \\
\text { slightly with } \\
\text { increasing } \\
\text { size on } \\
\text { nanometer } \\
\text { particle }\end{array}$ & $\begin{array}{l}\text { Gradual } \\
\text { increase }\end{array}$ \\
\hline
\end{tabular}

Table 2 shows researches on the particle size of different nanometers $\mathrm{Al}_{2} \mathrm{O}_{3}$ and $\mathrm{ZrO}_{2}$. 
It can be seen that for $\mathrm{Al}_{2} \mathrm{O}_{3}$ higher friction coefficient and lowest wear coefficient can be obtained at $15 \mathrm{~nm}$, by increasing the particle size of $\mathrm{Al}_{2} \mathrm{O}_{3}$ to $90 \mathrm{~nm} \& 500 \mathrm{~nm}$ the friction coefficient is lower and the wear coefficient is little more than twice of $15 \mathrm{~nm}$. When PTFE is added lower friction coefficient can be obtained but wear coefficient increased, when only PTFE is added it has lower wear coefficient than when it's not filled [15].

For $\mathrm{ZrO}_{2}$, when filled with less than $15 \mathrm{~nm}$ friction will be reduced and wear coefficient will sharply decreased. But when PEEK is filled with more than $50 \mathrm{~nm}$ wear rate is gradually increase and friction will increase less when the size of particles increases. It is found that all different size nanometer $\mathrm{ZrO}_{2}$ as fillers can make the friction less of the peek which is filled but when the nanometer size becomes more the coefficient of friction will become more on a small scale [16].

Table 3 PEEK filled nanometer SiC, nanometer $\mathrm{SiO}_{2}$ [19], nanometer $\mathrm{ZrO}_{2}$ [16] nanometer $\mathrm{Si}_{3} \mathrm{~N}_{4}$ [17], GO-Si [20], and graphite composites [22]

\begin{tabular}{|c|c|c|}
\hline \multicolumn{3}{|c|}{ PEEK filled Nanometer SiC } \\
\hline $\begin{array}{c}\text { Weight } \\
\text { percentage } \\
\text { Wt\% }\end{array}$ & Friction & Wear rate \\
\hline $\begin{array}{ll}<7.5 & \text { for } \\
\text { friction } & \\
<10 & \text { for } \\
\text { wear } & \end{array}$ & Decreased Sharply & Decreased Sharply \\
\hline $\begin{array}{l}20 \quad \text { for } \\
\text { friction } \\
<2.5 \text { for } \\
\text { wear }\end{array}$ & Lowest value & Decreased Sharply \\
\hline $2.5-10$ & - & $\begin{array}{l}\text { Lowest value and } \\
\text { nearly unchanged }\end{array}$ \\
\hline$>10$ & - & Linearly increased \\
\hline \multicolumn{3}{|c|}{ PEEK filled nanometer $\mathrm{SiO}_{2}$} \\
\hline Up to 5 et $\%$ & Decreased sharply & Decreased sharply \\
\hline $\begin{array}{l}\text { Increasing } \\
\mathrm{SiO}_{2} \\
\text { content }\end{array}$ & $\begin{array}{l}\text { Decreased } \\
\text { gradually }\end{array}$ & Increased gradually \\
\hline \multicolumn{3}{|c|}{ PEEK filled Nanometer $\mathrm{ZrO}_{2}$} \\
\hline Below7.5 & Increasing & Decreased sharply \\
\hline 7.5 & $\begin{array}{l}\text { Best frictional } \\
\text { coefficient }\end{array}$ & $\begin{array}{l}\text { Lowest value(best } \\
\text { wear coefficient) }\end{array}$ \\
\hline Above 7.5 & Decreasing & Linearly increasing \\
\hline
\end{tabular}

\begin{tabular}{|c|c|c|}
\hline \multicolumn{3}{|c|}{ PEEK filled Nanometer $\mathrm{Si}_{3} \mathrm{~N}_{4}$} \\
\hline $2.5-5$ & & Nearly unchanged \\
\hline $\begin{array}{ll}<7.5 & \text { for } \\
\text { friction } & \\
<2.5 & \text { for } \\
\text { wear } & \end{array}$ & Decrease sharply & Sharply decreased \\
\hline $\begin{array}{l}15 \text { for } \\
\text { friction } \\
7.5 \text { for wear }\end{array}$ & Lowest value & Lowest value(best) \\
\hline$>7.5$ & & Linearly increased \\
\hline 7.5 & Best & \\
\hline \multicolumn{3}{|c|}{ PEEK filled GO-Si } \\
\hline 0.1 & Lower friction & Higher wear life \\
\hline \multicolumn{3}{|c|}{ PEEK/graphite composites } \\
\hline $\begin{array}{l}<15 \text { for } \\
\text { friction } \\
<5 \text { for wear }\end{array}$ & Steady & Increase \\
\hline $\begin{array}{l}25 \text { for } \\
\text { friction } \\
>5 \text { for wear }\end{array}$ & $\begin{array}{l}\text { Significant } \\
\text { decrease(minimum) }\end{array}$ & Decrease \\
\hline$>25$ & Unchanged & \\
\hline
\end{tabular}

Table 3 shows friction coefficient and wear rates of different weight percentages of different nanometers.

For PEEK filled nanometer SiC, when it's filled with less than $7.5 \mathrm{wt} \%$ friction decreased sharply and when filled with less than $10 \mathrm{wt} \%$ wear rate decreased sharply. Friction has lowest value at $20 \mathrm{wt} \%$, and wear decreased sharply when its filled with less than $2.5 \%$, but at (2.510) wt $\%$ wear rate has lowest value and nearly unchanged, and above 10 its linearly increased with increasing $\mathrm{SiC}$ content and it is higher in comparison with the unfilled PEEK. For PEEK filled $\mathrm{SiO}_{2}$, friction coefficient and wear rate decrease sharply up to $5.0 \mathrm{wt} \%$. But with increasing $\mathrm{SiO}_{2}$ content friction decrease gradually and wear rate increase gradually. Usually, nanometer $\mathrm{SiO}_{2}$ filled PEEK composite exhibits a decreased wear coefficient in comparison with the neat PEEK. This illustrates that nanometer $\mathrm{SiO}_{2}$ is very effective in reducing the friction and wear of the filled PEEK [19].

For PEEK filled nanometer $\mathrm{ZrO}_{2}$, friction increased below $7.5 \mathrm{wt} \%$, but wear is decreased sharply, when the amount of $\mathrm{SiC}$ becomes more than the unfilled peek friction and wear resistance.

The unfilled peek has higher wear coefficient than the peek which is filled with $\mathrm{SiO}_{2}$ this shows that $\mathrm{SiO}_{2}$ has an important role in improving the friction and wear resistance. 
For the perfect union of friction and wear resistance the amount of $\mathrm{ZrO}_{2}$ should be 7.5 wt.\% [20].

For PEEK filled nanometer $\mathrm{Si}_{3} \mathrm{~N}_{4}$, when its filled with 2.5 - $5.0 \mathrm{wt} \%$, wear rate coefficient remain nearly unchanged. And when it's less than $7.5 \mathrm{wt} \%$ friction coefficient sharply decreased, but wear sharply decreased when it's less than $2.5 \mathrm{wt} \%$. Friction reaches lower value at $15 \mathrm{wt} \%$ but wear reaches lower value at $7.5 \mathrm{wt} \%$. The best weight percentage is 7.5 for friction and wears [17].

For PEEK filled GO-Si, lower friction can be obtained at $0.1 \mathrm{wt} \%$ with higher wear life rate [20].

It was shown that the coefficient of friction of pure peek was higher than the peek graphite composites of pure PEEK. When the content of graphite was below 15 $\mathrm{wt} \%$, the coefficient of friction was steady. And then it significantly decreased and reached the minimum at the graphite content of $25 \mathrm{wt} \%$. Above $25 \mathrm{wt} \%$, the coefficient of friction was nearly unchanged. As already known, graphite can help in improving the tribological performance of composite materials, attributing to its unique layer structure [22].

\section{Table 4 PEEK filled nanometer $\mathrm{CuS}$ [18]}

\begin{tabular}{|c|c|c|c|}
\hline \multicolumn{4}{|c|}{ PEEK filled Nanometer CuS } \\
\hline Filler & $\begin{array}{c}\text { Volume } \\
\text { percentage }\end{array}$ & Friction & Wear rate \\
\hline $\mathrm{CuS}$ & 35 vol. $\%$ & - & $\begin{array}{l}\text { Lowest wear(one } \\
\text { six the wear rate } \\
\text { of PEEK) }\end{array}$ \\
\hline \multirow{3}{*}{$\begin{array}{l}\text { Peek- } \\
\text { CuS- } \\
\text { PTFE }\end{array}$} & $\begin{array}{l}\text { PEEK } \\
\text { 30vol.\%CuS. }\end{array}$ & - & $\begin{array}{l}>(\text { Peek- } \\
\text { 30vol.\% } \\
\text { CuS5Vol.\%PTF } \\
\text { E) \& (PEEK- } \\
\text { 25vol.\%CuS- } \\
\text { 10vol.\%PTFE) }\end{array}$ \\
\hline & $\begin{array}{l}\text { Peek-30vol.\% } \\
\text { CuS- } \\
\text { 5Vol.\%PTFE }\end{array}$ & $\begin{array}{l}\text { PEEK } \\
30 \\
\text { vol. } \% \\
\mathrm{CuS}\end{array}$ & $\begin{array}{l}<\text { PEEK30vol. \% } \\
\text { CuS. }\end{array}$ \\
\hline & $\begin{array}{l}\text { PEEK- } \\
\text { 25vol.\%CuS- } \\
\text { 10vol.\%PTFE }\end{array}$ & $\begin{array}{l}\text { Further } \\
\text { reducing }\end{array}$ & $\begin{array}{l}<\text { PEEK30vol.\% } \\
\text { CuS. }\end{array}$ \\
\hline
\end{tabular}

Friction and wear resistance of PEEK when it's filled with nanometer $\mathrm{CuS}$ (with and without PTFE) is shown in Table 4.

The wear rates became less when it was filled with any amount of $\mathrm{CuS}$. The wear rate became minimum when we had PEEK- 35 vol. \% CuS and it was about one-sixth the wear rate of PEEK. When proportions of 5 vol. $\%$ and 10 vol. of PTFE were added, friction coefficient was reduced. When 5 wt. $\%$ was added it was reduced but when 10 wt. $\%$ was added it was further reduced. The wear rate of PEEK-30 vol. \% $\mathrm{CuS}$ are much higher than of PEEK-30 vol. \% CuS-5 vol. \%
PTFE and PEEK-25vol. \% CuS-10 vol. \% PTFE which had nearly the same wear rates [18].

\section{Table5 Short fiber reinforced PEEK composites [21]}

\begin{tabular}{|l|l|l|l|}
\hline \multicolumn{3}{|c|}{ Short fiber reinforced PEEK composites } \\
\hline $\begin{array}{c}\text { Sliding } \\
\text { velocity }\end{array}$ & $\begin{array}{c}\text { Normal } \\
\text { load }\end{array}$ & Friction & \multicolumn{1}{|c|}{ Wear } \\
\hline 100 rev/min & $12 \mathrm{~N}$ & $3.5-5.5 \mathrm{~N}$ & $\begin{array}{l}\text { lower wear } \\
\text { rate }\end{array}$ \\
\hline $\begin{array}{l}\text { Higher } \\
\text { velocity }\end{array}$ & $12 \mathrm{~N}$ & $3.5-5.5 \mathrm{~N}$ & $\begin{array}{l}(5-7.5) \text { times } \\
\text { higher }\end{array}$ \\
\hline $\begin{array}{l}\text { High } \\
\text { velocity }\end{array}$ & $5.5 \mathrm{~N}$ & $1.5-2 \mathrm{~N}$ & $\begin{array}{l}(4-6) \text { times } \\
\text { lower }\end{array}$ \\
\hline
\end{tabular}

Table 5 shows the wear rate under normal load of 12 $\mathrm{N}$ at $100 \mathrm{rev} / \mathrm{min}$. Fiber reinforcement lowers the wear rate of materials. It shows the effect of normal load and sliding velocity on short fiber reinforced composites, we can see that fiber reinforcement lowers the wear rate of materials. Under the same normal load of $12 \mathrm{~N}$, the revolution number (sliding velocity) affects the tribological behavior results strongly. Sliding velocity markedly affects the results. Wear rate is 5-7.5 times higher at higher sliding velocity. Under the normal load of $12 \mathrm{~N}$ all materials gives the friction force values between 3.5 and $5.5 \mathrm{~N}$. Under the normal load of $5.5 \mathrm{~N}$ friction forces decreases to 1.5 and $2 \mathrm{~N}$ [21].

\section{Table 6 PEEK-CF30/Steel [8]}

\begin{tabular}{|c|l|c|}
\hline \multicolumn{2}{|c|}{ PEEK-CF30/Steel } \\
\hline Temperature & \multicolumn{1}{|c|}{ Friction } & Wear rate \\
\hline $\begin{array}{l}\text { Increasing temp. to } \\
\text { about 90-100 } \mathrm{C}\end{array}$ & $\begin{array}{l}\text { Gradually } \\
\text { increasing to max. }\end{array}$ & - \\
\hline Further increasing & Decreases & - \\
\hline
\end{tabular}

As shown in Table 6, the prediction of friction coefficient of pair (PEEKCF30/steel) as function of contact temperature can be seen. For temperature to about $90-100{ }^{\circ} \mathrm{C}$, friction gradually increases to maximum. Friction coefficient decreases with further increasing of temperature [8]. 


\section{CONCLUSION}

(1) When 316L slides to CFRPEEK it shows the perfect friction and wear resistance, when it was compared to the pairs $316 \mathrm{~L}$ with peek and $9 \mathrm{Cr} 18 \mathrm{Mo}$ with CFRPEEK. The wear of 316L/CFRPEEK is lower than $9 \mathrm{Cr} 18 \mathrm{Mo} / \mathrm{CFRPEEK}$ and wear of $316 \mathrm{~L} / \mathrm{PEEK}$ is higher than $9 \mathrm{Cr} 18 \mathrm{Mo}$.

(2) We can see that when we add $\mathrm{Al}_{2} \mathrm{O}_{3}$ particles to PEEK wear rate can be decreased, but it cannot decrease the friction coefficient. It can reach minimum wear rate when the composite filled with 5 mass\% $15 \mathrm{~nm} \mathrm{Al}_{2} \mathrm{O}_{3}$. With 90 and $500 \mathrm{~nm} \mathrm{Al}_{2} \mathrm{O}_{3}$ filled PEEK; the increased wear coefficients can be seen. Friction and wear resistance are decreasing when we add 10 mass\% PTFE into unfilled PEEK, but when we add of 10 mass\% PTFE into PEEK friction is decreasing and wear is increasing.

(3) When we add $\mathrm{ZrO}_{2}$ we see that it has a good role in reducing wear when the nanometer size is less than $15 \mathrm{~nm}$. When nanometer size is increasing the wear rate also increases.

(4) When $\mathrm{SiC}$ is added to PEEK we see that it has a very important role in changing friction and wear. The best amount is about $7.5 \mathrm{wt}$. $\%$ to $10 \mathrm{wt} . \%$.

(5) When $\mathrm{SiO}_{2}$ is added to PEEK we see a great role in reducing friction and wear.

(6) When we add $7.5 \mathrm{wt}$.\% of nanometer $\mathrm{ZrO}_{2}$ to PEEK we see that it has best friction and wear.

(7) When we add $\mathrm{Si}_{3} \mathrm{~N}_{4}$ to PEEK we see that it affects friction and wear greatly. It can be seen that at $7.5 \mathrm{wt} . \%$ it has minimum wear rate.

(8) GO-Si as filler has an excellent role in affecting the friction and wear properties.

(9) The coefficient of friction of PEEK composites reached minimum at $25 \mathrm{wt} \%$. The smaller particle size of graphite effectively improved the wear resistance.

(10)When we add CF30 to PEEK, best friction and wear resistance can be obtained when slides against steel disc.

(11)So from the comparison of these data we come to new directions of filling the gaps in the field of studying the friction and wear resistance of PEEK when fillers were added to it.

\section{REFERENCES}

[1] K. Tanaka, "Effects of various fillers on the friction and wear of PTFE- based composites", in Friction and Wear of Polymer Composites, K. Friedrich (Ed.), Elsevier, pp. 137- 174, 1986.

[2] R. L. Fusaro, H. E. Sliney, "Friction and wear behavior of graphite fiber reinforced polyimide composites", ASLE Transactions, 21(4), pp. 1-14, 1978.
[3] Q. H. Wang, J. Xu, W. Shen, Q. Xue, "The effect of nanometer $\mathrm{SiC}$ filler on the tribological behavior of PEEK", Wear, 209 (1-2), pp. 316-321, 1997.

[4] T. Okabe, N. Takeda, "Size effect on tensile strength of unidirectional CFRP compositesexperiment and simulation", Composites Science and Technology, 62 (15), pp. 2053-2064, 2002.

[5] M. Sumer, H. Unal, A. Mimaroglu, "Evaluation of tribological behavior of PEEK and glass fiber reinforced PEEK composite under dry sliding and water lubricated conditions", Wear, 265 (7-8), pp. 1061-1065, 2008.

[6] J. P. Davim, N. Marques, A. M. Baptista, "Effect of carbon fiber reinforcement in the frictional behavior of PEEK in a water lubricated environment", Wear, 251 (1-12), pp. 1100- 1104, 2001.

[7] R. Prehn, F. Haupert, K. Friedrich, "Sliding wear performance of polymer composites under abrasive and water lubricated conditions for pump applications", Wear, 259 (1-6), pp. 693- 696, 2005.

[8] X. Liujie, J. P. Davim, R. Cardoso, "Prediction on tribological behavior of composite PEEK-CF30 using an artificial neural networks", Journal of Materials Processing Technology, 189 (1-3), pp. 374-378, 2007.

[9] J. P. Davim, R. Cardoso, "Effect of the reinforcement (carbon or glass fiber) on friction and wear behavior of the PEEK against steel surface at long dry sliding", Wear, 266 (7-8), pp. 795-799, 2009.

[10] J. P. Davim, R. Cardoso, "Tribological behavior of the composite PEEK-CF30 when dry sliding against steel using statistical techniques", Materials \& Design, 27 (4), pp. 338- 342, 2006.

[11] J. P. Davim, N. Marques, "Evaluation of tribological properties of polymeric materials for hip prosthesis applications", Tribology Letters, 11(2), pp. 91-94, 2001.

[12]H. Voss, K. Friedrich, "On the wear behavior of short-fiber-reinforced PEEK composites", Wear, 116(1), pp. 1-18, 1987.

[13] N. Marques, J. P. Davim, “Tribological comparative study of conventional and composite materials for biomedical applications", Key Engineering Materials, 230-232, pp. 487-490, 2002.

[14]Z. Wang, D. Gao, "Friction and wear properties of stainless steel sliding against polyetheretherketone and carbon-fiber-reinforced polyetheretherketone under natural seawater lubrication", Materials \& Design, 53, pp. 881-887, 2014.

[15] H. B. Qiao, Q. Guo, A. G. Tian, G. L. Pan, L. B. $\mathrm{Xu}$, "A study on friction and wear characteristics of nanometer $\mathrm{Al}_{2} \mathrm{O}_{3}$ /PEEK composites under the dry sliding condition", Tribology International, 40 (1), pp. 105- 110, 2007.

[16] Q. Wang, Q. Xue, H. Liu, W. Shen, J. Xu, "The effect of particle size of nanometer $\mathrm{ZrO} 2$ on the tribological behavior of PEEK”, Wear, 198 (1-2), pp. 216-219, 1996. 
[17] Q. H. Wang, J. Xu, W. Shen, Q. Xue, "The effect of nanometer SiC filler on the tribological behavior of PEEK", Wear, 209 (1-2), pp. 316- 321, 1997.

[18] J. V. Voort, S. Bahadur, "The growth and bonding of transfer film and the role of CuS and PTFE in the tribological behavior of PEEK", Wear, 181- 183(1), pp. 221- 221, 1995.

[19] Q. H. Wang, J. Xu, W. Shen, W. Liu, "An investigation of the friction and wear properties of nanometer $\mathrm{Si}_{3} \mathrm{~N}_{4}$ filled PEEK", Wear, 196 (1-2), pp. 82-86, 1996.

[20]H. J. Song, N. Li, Y. Li, C. Min, Z. Wang, "Preparation and tribological properties of graphene/ poly (ether ether ketone) nano composites", Journal of Materials Science, 47 (17), pp. 6436- 6443, 2012.
[21]T. Sinmazcelik, T. Yilmaz, "Thermal aging effects on mechanical and tribological performance of PEEK and short fiber reinforced PEEK composites", Materials \& Design, 28 (2), pp. 641648, 2007.

[22] Y. S. Shang, Y. Zhao, Y. Liu, Y. Zhu, Z. Jiang, H. Zhang, "The effect of micron-graphite particle size on the mechanical and tribological properties of PEEK composites", High Performance Polymers, doi.org/10.1177/0954008316685410, 2017. 